\title{
Pengaruh Materialitas, Etika Auditor dan Independensi Auditor Terhadap Opini Audit
}

\author{
Haikal Rafif Ilhamsyah, Anita Nopiyanti \\ Ayunita Ajengtiyas Saputri Mashuri \\ Universitas Pembangunan Nasional "Veteran" Jakarta \\ EMail: haikal.rafif@upnvj.ac.id
}

\section{ABSTRACT}

This research is using quantitive study aimed to see whatever there are the effect of materiality, auditor ethics and auditor independence on the provision of giving audit opinion. This study uses primary data with respondents are senior auditors working in accountant publik firm in the DKI Jakarta. Testing the hypothesis in the study was used Multiple Linier Regression Analysys using SPSS analisys tool with a significant level of 5\% $(0,05)$. The Result of these test indicate that (1) there is significant influence materiality on provision of audit opinion, (2) there is no significant influence auditor ethics on provision of audit opinion, (3) there is no significant influence auditor independence on provision of audit opinion.

Keywords: materiality, auditor ethics, auditor independence, and provision of audit opinion.

\begin{abstract}
ABSTRAK
Penelitian ini merupakan penelitian kuantitatif yang bertujuan untuk mengetahui pengaruh materialitas, etika auditor dan independensi auditor terhadap ketetapan pemberian opini audit. Penelitian ini menggunakan data primer dengan responden pada penelitian ini adalah auditor senior yang bekerja di Kantor Akuntan Publik diwilayah DKI Jakarta. Pengujian hipotesis ini menggunakan Analisis Regresi Berganda dengan program SPSS dan tingkat signifikansi $5 \%(0,05)$. Hasil dari pengujian diperoleh (1) terdapat pengaruh signifikan materialitas terhadap ketetapan pemberian opini audit, (2) terdapat pengaruh secara tidak signifikan etika auditor terhadap ketetapan pemberian opini audit, (3) terdapat pengaruh secara tidak signifikan independensi auditor terhadap ketetapan pemberian opini audit.
\end{abstract}

Kata Kunci : materialitas, etika auditor, independensi auditor, dan ketetapan pemberian opini audit.

\section{PENDAHULUAN}

Seiring berjalannya waktu, dunia banyak mengalami perubahan dan persaingan menjadi semakin keras. Hal ini membuat perusahaan bersaing ketat satu sama lain untuk menjadi lebih baik. Salah satu yang menjadi dasarnya adalah pembentukan laporan keuangan, laporan keuangan disusun dengan tujuan untuk menyampaikan keterbukaan berita ke berbagai pihak yang berkepentingan seperti pemegang saham, kreditor dan manajemen perusahaan. Auditor menjadi peranan penting dalam mendapatkan bukti asersi tentang kegiatan ekonomi suatu perusahaan dalam laporan keuangan, serta menginformasikan hasilnya kepada pihak yang berkepentingan. Tujuannya untuk melaporkan tingkat kesesuaian mengenai kriteria yang diberikan, sehingga opini yang diberikan auditor independen terhadap informasi yang diberikan.
433

Submitted:

OKTOBER 2020

Accepted:

DESEMBER 2020

\section{JIAKES}

Jurnal Ilmiah Akuntansi Kesatuan Vol. 8 No. 3, 2020

pg. $433-440$

IBI Kesatuan ISSN 2337 - 7852
E-ISSN 2721 - 3048 
Auditor Quality

and Audit

Opinion
Opini audit ialah perkataan auditor tentang kesesuaian laporan keuangan dari perusahaan yang diaudit. Kesesuaiaan itu meliputi materialitas , laba rugi, posisi keuangan, dan arus kas. Opini audit menjadi "diartikan "laporan keuangan yang digunakan pengguna dalam mengambil keputusan untuk kinerja perusahaan. Opini audit diatur dalam standar audit 700 mengenai tanggung jawab auditor dalam menerbitkan opini akan laporan keuangan. Standar audit juga mentertibkan wujud laporan auditor yang diusulkan berupa hasil audit atas laporan keuangan. Standar audit 705 dan 706 juga mengelola gimana isi dan gambaran laporan auditor kala auditor menyampaikan opini modifikasi maupun mengisikan paragraf penakanan dalam laporan audit.

Ada kejanggalan dalam laporan keuangan PT Asuransi Jiwasraya di 2017. Laporan keuangan memperoleh opini adverse atau dengan modifikasi dari Kantor Akuntan Publik PricewaterhouseCoopers $(\mathrm{PwC})$ walaupun telah diperbaiki. Pada laporan keuangan Jiwasraya di 2017 yang telah diaudit tertulis perusahaan memperoleh laba Rp 360 miliar. Angka tersebut seharusnya sudah dalam revisi setelah diaudit $\mathrm{PwC}$ dari sebelumnya Rp 2,4 triliun. Akan tetapi, walaupun telah diperbaiki PwC tetap memberikan opini 'Dengan Modifikasian'. Ketua Umum Institut Akuntan Publik Indonesia (IAPI ) Tarkosunaryo menilai ada kejanggalan ketika Jiwasraya menampilkan laporan keuangan 2017. Menurut Tarko opini modifikasi tersebut seharusnya dipantau. Status modifikasian artinya ada hal yang tidak benar dalam laporan keuangan tersebut. "Opini auditor akuntan publik adalah opini tidak wajar karena kekurangan cadangan teknis Rp 7 triliun. Jadi laba Rp 360 miliar yang disampaikan direksi adalah tidak tepat," tambahnya . Bagi perusahaan asuransi setiap adanya pendapatan premi maka perusahaan harus menyiapkan cadangan teknis. Jika cadangan teknis tidak ada maka perusahaan itu bisa mengalami kerugian karena gagal bayar. Menurut tarko pihak yang bertanggung jawab adalah manajemen sebab laporan keuangan dibuat direksi dan dipantau oleh manajemen.

\section{Pengembangan Hipotesis}

Pengaruh Materialitas Terhadap Ketetapan Pemberian Opini Audit. Menurut Penelitian Bharata dan Wiratmaja (2017) menunjukan bahwa kemampuan pertimbangan materialitas dapat memperkuat pengaruh positif kompetensi pada ketepatan pemberian opini oleh auditor, ini berarti dalam situasi seorang auditor memiliki kemampuan pertimbangan materialitas maka pengaruh positif kompetensi pada ketepatan pemberian opini menjadi semakin kuat .

H1: Tingkat Materialitas berpengaruh positif terhadap ketetapan pemberian opini audit.

Pengaruh Etika Auditor Terhadap Ketetapan Pemberian Opini Audit. Hasil penelitian Laila, (2019) Jika auditor dapat menjaga keselarasan dalam etika profesinya, ia akan dapat melaksanakan auditnya dengan baik sesuai yang diharuskan dalam kode etik profesi. Berdasarkan penelitian dan teori sebelumnya mengenai tingkat materialitas dan pengaruhnya terhadap opini audit sudah diterangkan diatas, maka disusun hipotesis penelitian sebagai berikut;

H2: Etika Auditor berpengaruh positif terhadap ketetapan pemberian opini audit.

Pengaruh Independensi Auditor Terhadap Ketetapan Pemberian Opini Audit. Menurut (Chandra, 2013) Pada penelitian sebelumnya yang dilakukan oleh Wijaya (2011), menunjukkan bahwa independensi auditor, pengetahuan auditor dan pengalaman kerja auditor berpengaruh secara signifikan pada pertimbangan pemberian opini audit. Didukung juga dengan hasil penelitian mayangsari (2003), bahwa pendapat auditor ahli dan independen berbeda dengan auditor yang hanya memilki satu karakter atau sama sekali tidak mempunyai karakter tersebut. Auditor independen meberikan pendapat yang lebih tepat dibandingkan dengan auditor yang tidak independen.

H3: Independensi Auditor berpengaruh positif terhadap ketetapan pemberian opini audit 


\section{METODE PENELITIAN}

\section{Populasi, Sampel, dan Metode}

Populasi ialah sekelompok orang, kejadian atau segala sesuatu yang mempunyai ciri tertentu . Populasi dalam penelitian ini adalah para auditor yang bekerja di Kantor Akuntan Publik di Jakarta . Sampel menurut Indriantoro dan Supomo (1999) adalah sebagian anggota dari populasi yang dipilih dengan menggunakan proses tertentu sehingga dapat mewakili populasi. Populasi pada penelitian ini adalah auditr di Kantor Akuntan Publik (KAP) di daerah DKI Jakarta yang terdaftar di Direktori Ikatan Akuntan Publik Indonesia (IAPI ) dan Otoritas Jasa Keuangan (OJK) sebanyak 286 KAP dengan anggota akuntan publik yang terdaftar sebanyak 832. Penelitian ini menggunakan sampel auditor yang pernah menjadi senior auditor eksternal dan diatasnya yang bekerja di KAP DKI Jakarta. Metode probability sampling digunakan dalam penelitian ini untuk jenis sampelnya yaitu Random Sampling. Random sampling merupakan teknik penentuan sampel menggunakan anggota sampel secara acak dari populasi. Metode pengujian hipotesis yang dilakukan pada penelitian ini adalah analisis regresi linier berganda.

\section{Definisi Operasional Variabel}

Hasil opini auditor ialah suatu pendapat yang dinyatakan oleh auditor tentng kewajaran dalam peyajian laporan keuangan perusahan dimana auditor melakukan audit . Opini yang paling baik ialah wajar tanpa pengeculian (unqualified opinion ). Opini ini akan diberikan ketika auditor merasa yakin, terhadap bukti-bukti audit. Pemberian opini audit ialah tanggungjawab seorang auditor, dimana akuntan publik memberikan pendapatnya terhadap kewajaran laporan keuangan yang disusun oleh manajemen dan menjadi tanggungjawab manajamen.

Menurut (Laila, 2019 Materialitas ialah keahlian auditor dalam menyajikan informasi akuntansi atas penghapusan atau salah saji laporan keuangan yang dapat mempengaruhi pertimbangan orang dalam pengambilan keputusan. Etika Auditor ialah bagaimana seorang auditor dalam membuat keputusan pasti menggunakan lebih dari satu pertimbangan rasional yang didasarkan pemahaman etika yang berlaku dan membuat suatu keputusan yang adil (fair) serta tindakan yang diambil itu harus menirukan kebenaraan dan kondisi yang sebenarnya. Independensi profesional terbagi menjadi tiga komponen, yaitu independensi dalam program audit, independensi dalam verifikasi dan independensi dalam pelaporan.

\section{HASIL DAN PEMBAHASAN \\ Uji Normalitas}

Table 1. One-Sample Kolmogorov-Smirnov Test

\section{$\mathrm{N}$}

Normal Parameters ${ }^{\mathrm{a}, \mathrm{b}}$

$\begin{array}{ll}\text { Normal Parameters }^{\mathrm{a}, \mathrm{b}} & \text { Std. Deviation } \\ & \text { Absolute } \\ \text { Most Extreme Differences } & \text { Positive } \\ & \text { Negative }\end{array}$

Test Statistic

Asymp. Sig. (2-tailed)
Unstandardized Residual

18

0

$$
\begin{gathered}
0,86992035 \\
0,185 \\
0,174 \\
-0,185 \\
0,185 \\
, 103^{c}
\end{gathered}
$$

Auditor Quality

and Audit

Opinion

Sumber: Data Primer Diolah

Berdasarkan tabel 1 diatas, nilai Asymp. Sig (2-tailed) sebesar 0,103 lebih besar dari nilai signifiknsi sebesar 0,05 , maka dapat dinyatakan dalam penelitian ini berdistribusi normal. 
Auditor Quality

and Audit

Opinion

$\underline{436}$
Uji Koefisien Determinasi (Adjusted R2)

Tabel 2. Hasil Statistik Uji Koefisien Determinasi

\begin{tabular}{lrrrr} 
Model & \multicolumn{2}{c}{ Model Summary $^{b}$} \\
1 & $R$ & $R$ Square & Adjusted $R$ Square \\
1 & & $960^{\mathrm{a}}$ & 0,921 & 0,904
\end{tabular}

Nilai koefisien nilai determinasi yang sudah disesuaikan (Adjusted $R$ Square) adalah 0,904 pada tabel 22 artinya $90,4 \%$ variasi dari ketetapan pemberian opini audit bisa dijelaskan oleh variasi variabel bebas (materialitas, etika auditor dan independensi auditor). Untuk sisanya $(100 \%-90,4 \%=9,6 \%)$ dijelaskan oleh variabel lain yang tidak ada dalam penelitian ini seperti kode etik (Laila,2019), skeptisme profesional (Fiastri, 2018), keahlian audit (Merici, 2014).

Uji Parsial t (Uji t)

Tabel 3. Hasil Uji Statistik t

\begin{tabular}{lcc}
\multicolumn{1}{c}{ Model } & $\mathbf{t}$ & Sig \\
(Constant) & 0,837 & 0,417 \\
MAT & 3,430 & 0,004 \\
ETC & 1,138 & 0,274 \\
IND & 0,876 & 0,396
\end{tabular}

Sumber Data Primer Diolah

Pada tabel 3 di atas memperlihatkan pengaruh materialitas, etika auditor dan independnsi auditor terhadap ketetapan pemberian opini audit menunjukkan hasil dari nilai t hitung dan tingkat signifikansi. Jika dilihat dari tabel distribusi t, dimana jumlah sampel (n) sebanyak 18 dan jumlah variabel sebanyak $3, \mathrm{df}=15$, nilai tabel $\mathrm{t}$ adalah 2,13145 .

Variabel materialitas dengan nilai t hitung sebesar 3,430 > 2,13145 atau nilai signifikasi sebesar 0,005 lebih kecil dari nilai signifikansi sebesar 0,05, oleh karena itu dapat disimpulkan bahwa Ha diterima dan Ho ditolak yang artinya materialitas berpengaruh positif signfikan secara parsial terhadp ketetapan pemberian opini audit. Variabel etika auditor dengan nilai $t$ hitung sebesar $1,138<2,13145$ atau nilai signifikansi lebih besar dari 0,05, maka dapat disimpulkan bahwa Ha ditolak dan Ho diterima yang berarti etika auditor tidak berpengaruh secara parsial terhadap ketetapan pemberian opini audit.

Variabel independensi auditor dengan nilai t hitung sebesar 0,876 $<2,13145$ atau nilai sig. Lebih besar dari 0,05, maka dapat disimpulkan bahwa Ha ditolak dan Ho diterima yang berarti independensi auditor tidak berpengarh secara parsial terhadap ketetapan pemberian opini audit.

\section{Pembahasan}

\section{Pengaruh Materialitas terhadap Ketetapan Pemberian Opini Audit}

Berdasarkan hasil olah data dari kuesioner, pada variabel materialitas dari 18 responden, 4 responden menjawab setuju jika ketetapan pemberian opini audit dipengaruhii variabel materialitas atau sebesar $22 \%$ setuju bahwa ketetapan pemberian opini audit dipengaruhi variabel materialitas dan 13 responden menjawab sangat setuju ketetapan pemberian opini audit dipengaruhi variabel materialitas atau sebesar $72 \%$ sangat setuju ketetapan pemberian opini audit dipengaruhi variabel materialitas . Pada variabel materialitas nilai minimal sebesar 1,11 yang dapat diartikan auditor kurang baik dalam menguji materialitas dalam memberikan opini audit sedangkan nilai maksimal sebesar 4 yang dapat diartikan auditor sangat baik dalam menguji materialitas untuk memberikan opini audit. Nilai rata ratta dari variabel materialitas sebesar 3,67 sedangkan ketetapan pemberian opini audit adalah 3,77 artinya pemberian opini audit tidak dipengaruhi oleh materialitas karena hasil dari nilai ratarata materialitas lebih kecil dibandingkan dengan hasil rata rata dari variabel ketetapan pemberian opini audit. Hasil uji yang dilakukan antara variabel materialitas dengan 
ketetapan pemberian opini audit menyatakan bahwa terdapat hasil nilai Thitung sebesar $3,430>2,13145$ atau nilai signifikasii sebesar 0,005 lebih kecil dari nilai signifkansi sebesar 0,05 , artinya ketetapan pemberian opini audit dipengaruhi secara signifikan terhadp materialitas.

Materialitas merupakan pertimbangan profesional dan dipengaruhi oleh asumsi auditor atas kebutuhan para pengguna laporan keuangan. Materialitas adalah besarnya informasi akuntansi yang apabila terjadi penghilangan atau salah saji terhadap keadaan yang lingkupinya mungkin dapat mengubah atau mempengaruhi pertimbangan orang yang meletakkan kepercayaan atas informasi tersebut (SA Seksi 312, SPAP, 2012). Tinggi rendahnya tingkat materialitas yang diperiksa oleh auditor dapat menyimpulkan opini yang diberikan oleh Kantor Akuntan Publik (KAP) tehadap suatu perusahaan. Auditor dapat menentukan tingkat materialitasnya jika sudah lama bekerja dalam KAP. Materialitas dapat membantu auditor untuk memberikan opini kepada perusahaan yang diauditnya. Masalah materialitas bisa diatasi jika auditor transparan terhadap laporan keuangan perusahaan yang diauditnya.

Hasil penelitian ini sesuai dengan penelitian sebelumnya yang dilakukan oleh feriyanto (2017) dan Laila (2019), auditor yang dapat mengukur jika tingkat materialitas itu rendah berarti perusahaan dapat menghasilkan hasil opini yang baik. Auditor dapat menguji tingkat materialitas dengan mengaudit laporan keuangan perusahaan yang diauditnya untuk menentukan hasil opini auditnya.

Pengaruh Etika Auditor terhadap Ketetapan Pemberian Opini Audit

Berdasarkan hasil olah data dari kuesioner, pada variabel etik auditor dari 18 responden, 16 responden menjawab sangat setuju bahwa variabel etika auditor mampu meningkatkan ketetapan pemberian opini audit atau sebesar $89 \%$ responden menyetujui variabel etika auditor dapat meningkatkan ketetapan pemberian opini audit. Pada variabel etika auditor nilai minimal sebesar 1,11 yang dapat diartikan auditor tidak memiliki etika baik sedangkan nilai maksimal sebesar 4 yang dapat diartikan auditor memiliki etika baik. Nilai rata rata dari variabel etika sebesar 3,82 sedangkan untuk variabel ketetapan pemberian opini audit adalah 3,77 artinya pemberian opini audit dapat ditingkatkan oleh variabel etika auditor memiliki pengaruh yang besar karena hasil dari nilai rata-rata etika auditor lebih besar dibandingkan dengan hasil rata rata dari variabel ketetapan pemberian opini audit. Hasil uji yang dilakukan antara variabel etika auditor dengan ketetapan pemberian opini audit menyatakan bahwa terdapat hasil nilai t hitung sebesar $1,138<2,13145$ atau nilai signifikansi lebih besar dari 0,05 , artinya etika auditor tidak berpengaruh terhadap ketetapan pemberian opini audit.

Etika secara garis besar dapat didefinisikan sebagai serangkaian prinsip atau nilai moral. Setiap orang mempunyai rangkaian nilai seperti itu, meskipun memperhatikan atau tidak memperhatikannya secara eksplisit. Etika mencakup tanggung jawab profesi, integritas, dan objektivitas (Fiastri, 2018). Sikap dan etika yang dimiliki oleh auditor dapat menentukan auditor dalam menyampaikan opini nya ke publik. Auditor pasti memiliki etika profesi dalam menjalakan auditnya.

Hasil penelitian ini sama dengan penelitian yang dilakukan oleh Nur DP (2014) dan Laila (2019), suatu etika dapat memberikan hasil dan dampak lainnya. Etika yang dimiliki auditor sering menjadi acuan dalam menjalankan audit dan menghasilkan opini audit atas laporan keuangan. Sehingga etika kadang kurang diterapkan karena adanya kesempatan untuk melanggar etika tersebut. Auditor harus memiliki keyakinan dan tekad terhadap etika untuk menunjang opini yang baik.

\section{Pengaruh Independensi Auditor terhadap Ketetapan Pemberian Opini Audit.}

Berdasarkan hasil olah data dari kuesioner, pada variabel independensi auditor dari 18 responden, 16 responden menjawab sangat setuju bahwa variabel independensi auditor mampu meningkatkan ketetapan pemberian opini audit atau sebesar $89 \%$ responden 
Auditor Quality

and Audit

Opinion menyetujui variabel independensi auditor dapat meningkatkan ketetapan pemberian opini audit. Pada variabel independensi auditor nilai minimal sebesar 1,11 yang dapat diartikan sikap independensi auditor kurang baik sedangkan nilai maksimal sebesar 4 yang dapat diartikan sikap independensi auditor sangat baik. Nilai rata rata dari variabel independensi sebesar 3,80 sedangkan untuk variabel ketetapan pemberian opini audit adalah 3,77 artinya pemberian opini audit dapat ditingkatkan oleh variabel independensi auditor memiliki pengaruh yang besar karena hasil dari nilai rata-rata etika auditor lebih besar dibandingkan dengan hasil rata rata dari variabel ketetapan pemberian opini audit. Hasil uji yang dilakukan antara variabel etika auditor dengan ketetapan pemberian opini audit menyatakan bahwa terdapat hasil nilai t hitung sebesar $0,876<2,13145$ atau nilai sig. lebih besar dari 0,05, artinya independensi auditor tidak berpengaruh terhadap ketetapan pemberian opini audit.

Independensi Auditor ialah kondisi yang terbebas dari pengaruh, bukan memihak, tidak tertekan dan terbebas dari kepentingan dari pihak manapun (Biksa \& Wiratmaja, 2016, dan Sanjaya, 2017). Auditor harus memiliki Sikap independensi seperti bebas dari tekanan, rasa percaya diri dan tidak memiliki ikatan keluarga dalam menjalankan audit laporan keuangan. Auditor harus menjaga kode etik profesi seperti tetap bersikaap independen terhadap klien perusahaan.

Hasil penelitian ini sama dengan penelitian sebelumnya yang dilakukan oleh Sanjaya (2017) dan Merici (2014 ), Independensi merupakan sikap yang wajib dimiliki oleh auditor untuk menghasilkan audit yang objektif. Sikap independensi auditor dapat mengungkapkan fakta tanpa ada rasa ragu karena auditor tidak memiliki hubungan khusus dan kepentingan kepada pihak manapun.

\section{PENUTUP}

Tujuan yang ingin dicapai dari penelitian ini adalah untuk menguji dan mengetahui secara empiris pengaruh Materialitas, Etika auditor dan Independensi auditor terhadap ketetapan pemberian opini audit. Setelah dilakukan analisis dan pembahasan pengujian hipotesis Materialitas, Etika auditor dan Independensi auditor terhadap ketetapan pemberian opini audit. Maka dari seluruhnya dapat ditarik kesimpulan bahwa secara parsial Materialitas berpengaruh secara signifikan terhadap ketetapan pemberian opini audit. Secara parsial Etika auditor tidak berpengaruh secara tidak signifikan terhadap ketetapan pemberian opini audit. Secara parsial Independensi auditor tidak berpengaruh secara tidak signifikan terhadap ketetapan pemberian opini audit.

Penelitian ini memiliki keterbatasan yang mempengaruhi hasil dari penelitian, adapun keterbatasan tersebut yaitu penyebaran kuesioner melalui google form kepada responden menyebabkan peneliti sulit untuk mendapatkan data karena tidak semua responden mau untuk mengisi kuesioner lewat google form. Keterbatasan waktu dalam pengisian kuisoner dan terjadinya kasus virus corona membuat sebagian besar KAP tidak dapat menerima kuesioner dari pihak luar karena rata rata auditor bekerja dari rumah (WFH) untuk menghindari kontak secara langsung.

\section{DAFTAR PUSTAKA}

Arens, A. A., Elder, R. J. and Beasley, M. (2014). Auditing dan Jasa Assurance: Pendekatan Teintegrasi. Edisi kelimabelas, Buku 1. Jakarta: Erlangga.

Arma Kharsima Arditiyan, Dhini Suryandari. (2016). Influences Of Experiences, Competencies, Independence and Professional Etchics Toward The Accuracy Of Audit Opinion Delivery Through Auditor's Professional Skepticism as An Intervening. Accounting Analysis Journal, ISSN : 2252-6765.

Biksa, I. A. I. and Wiratmaja, I. S. N. (2016). Pengaruh Pengalaman, Independensi, Skeptisme Profesional Auditor Pada Pendeteksian Kecurangan, E-Jurnal Akuntansi 
Universitas Udayana, Vol. 17, ISSN : 2302-8556.

Cholifah Husti Laila, Novita. (2019). Pengaruh Kode Etik, Materialitas Audit, dan Risiko Audit Terhadap Opini Auditor, E-Jurnal Akuntansi Universitas Bengkulu. DOI : Https://doi.org/10.33369/j.akuntansi.9.1.63-82. ISSN : 2303-0356.

CNN Indonesia. (2019). Kronologi Kasus Jiwasraya Versi OJK. Diakses 28 Maret 2020, dari https://www.cnnindonesia.com/ekonomi/20191230095752-78-460918/kronologikasus-gagal-bayar-jiwasraya-versi-ojk.

Cooper, D.R. and Emory, C.W. (2007). Metode Penelitian Bisnis. 5th edn. Jakarta: Erlangga.

Cresensia Anggela Merici, Abdul Halim, Retno Wulandari. ( 2014). Pengaruh Skeptisme Profesional, Pengalaman Audit, Keahlian Audit, Independensi, dan Kompetensi Terhadap Ketetapan Pemberian Opini Audit Pada KAP Kota Malang, Jurnal Akuntansi \& Manajemen Universitas Kanjuruhan. ISSN : 2337-5663.

Cynthia Fiastri, Siska Priyandini Yudowati. (2018). Pengaruh skeptisme profesional, etika, independensi, dan pengalaman auditor terhadap opini audit, E-proceeding of Management. ISSN : 2355-9357.

Danang Sugianto. (2020). Lapkeu Jiwasraya di 2017 Sudah Dikoreksi Tapi Masih DicapModifikasi.Diakses28Maret2020,darihttps://finance.detik.com/moneter/d4857723/lapkeu-jiwasraya-di-2017-sudah-dikoreksi-tapi-masih-dicap-modifikasian.

Emrinaldi Nur DP, Julita, Dwi Putra Wahyudi. (2014). Pengaruh Etika , Kompetensi , Pengalaman Auditor Dan Situasi Audit Terhadap Ketepatan Pemberian Opini Audit Melalui Pertimbangan Materialitas Dan Skeptisisme Profesional Auditor, Jurnal Ilmiah STIE MDP. Vol. 3 No. 2.

E. Abdul Wahab, M. Zain, R.Rahman. (2013). Political connections, Fees Paid to Auditors and Auditor Independence in Malaysia : Evidence From Going Concern Audit Opinions. International Journal of Accounting, Auditing and Performance Evaluation, Vol.9 No.2. DOI: 10.1504/IJAAPE.2013.0543.

Farihah Sulmaihati. (2020). Kementrian BUMD Desak BPK Blak-Blakan Soal Temuan Audit Jiwasraya. Diakses 28 Maret 2020, dari https://katadata.co.id/berita/2020/01/07/kementerian-bumn-desak-bpk-blak-blakansoal-temuan-audit-jiwasraya.

Fransisco, Fransiskus, Indri, Pordinana, Rara, Rizki, Zulmanto, and Umar,H. (2019). Pengaruh Kompetensi, Independensi dan Tekanan Waktu Terhadap Kemampuan Auditor Mendeteksi Kecurangan dengan Skeptisisme Profesional Sebagai Variabel Intervening, Prosiding Seminar Nasional Pakar ke 2 Tahun 2019, ISSN : 2615 - 2584.

Ghozali, I. (2018). Analisis Multivariate dengan Program IBM SPSS 25. Semarang: Badan Penerbit Universitas Diponegoro. ISBN : 979-704-015-1.

I. A. Putu Chandra Mitha Swari, I. Wayan Ramantha. (2013). Pengaruh Independensi dan Tiga Kecerdasan Terhadap Pertimbangan Pemberian Opini Audit, E-Jurnal Akuntansi Universitas Udhayana. ISSN : 2302-8556.

Institut Akuntan Publik Indonesia. (2012). Standar Profesional Akuntan Publik. Jakarta: Salemba Empat.

Irma Paramitha Sofia, Risha Trisantya Damayanti. (2017). Pengaruh Pengalaman, Profesionalisme, dan Etika Profesi Auditor Terhadap Penentuan Tingkat Materialitas. Jurnal Akuntansi Bisnis, Vol.4 No. 2, ISSN : 2337-7313.

Oon Feriyanto, Susilawati, Dadang. (2017). Pengaruh Profesionalisme Auditor Dan Pertimbangan Tingkat Materialitas Terhadap Ketepatan Pemberian Opini, STAR Study \& Accounting Research. ISSN : 1693-4482.

Parta setiawan. (2020). https://www.gurupendidikan.co.id/opini-audit/

Rachmad Catur Hariady, Haryanto. (2017). Pengaruh Profesionalisme Auditor dan Kualitas Audit Terhadap Pertimbangan Tingkat Materialitas Studi Kasus Pada Badan
Auditor Quality

and Audit

Opinion

439 
Auditor Quality and Audit

Opinion

$\underline{440}$
Pemeriksaan Keuangan Provinsi Jawa Tengah, E-jurnal Akuntansi Universitas Diponegoro, Vol.6 No.1, ISSN : 2337-2806.

Sanjaya, A. (2017). Pengaruh Skeptisisme Profeional, Independensi, Kompetensi, Pelatihan Auditor, dan Resiko Audit Terhadap Tanggung Jawab Auditor dalam Mendeteksi Kecurangan, Jurnal Akuntansi Bisnis, Vol. 15 No. 1, ISSN : 1412-775X.

Sianturi dan Nina. (2019). Pengaruh Independensi, Kompetensi, dan Integritas Terhadap Pemberian Opini Audit. E-Jurnal Akuntansi Universitas Prof Dr. Hazairin, Vol.2 No.2, ISSN : 2620-8555.

Suartana, I wayan. (2010). " Akuntansi Keperilakuan Teori dan Implementasi". Yogyakarta : Penerbit Andi.

Sugiyono. (2010). Metode Penelitian Pendidikan (Pendekatan Kuantitatif, Kualitatif dan R\&D). Bandung: Alfabeta. 